\title{
THE EFFECT OF ECONOMIC GROWTH, HDI, DISTRICT/CITY MINIMUM WAGE AND UNEMPLOYMENT ON INEQUALITY OF INCOME DISTRIBUTION IN PROVINCE OF D.I YOGYAKARTA (2010-2018)
}

\author{
Krisna Gita Suryani \\ IESP Department, Faculty of Economics and Business, Diponegoro University \\ Email: krisnagita189@gmail.com (corresponding author) \\ Nenik Woyanti \\ IESP Department, Faculty of Economics and Business, Diponegoro University \\ Email: neniwoyanti346@gmail.com
}

Received: January 2021; Accepted: March 2021; Available online: July 2021

\begin{abstract}
The high inequality of income distribution that occurs in the Special Region of Yogyakarta Province shows that economic development has not succeeded in bringing equity to the community. For this reason, an analysis is needed to determine the factors that inequality of income distribution in order to reduce inequality of income distribution that occurs in the Province of DI Yogyakarta. The purpose of this study was to determine the effect of economic growth, HDI, Distric/City Minimum Wage, and Unemployment. This research uses secondary data obtained from the Central Statistics Agency of D.I Yogyakarta Province. The data in this research is panel data consisting of cross section data from 5 districs/cities and time series data for 2010-2018. The data analysis used was panel data regression analysis with the Fixed Effect regression model. The results of the regression analysis show that economic growth does not have a significant effect on inequality of income distribution. Meanwhile, HDI, Distric/City Minimum Wages and Unemployment have a significant effect on the inequality of income distribution. HDI has a negative effect, while Distric/City Minimum Wage and Unemployment have a positive effect on inequality of income distributed in the Province of DI Yogyakarta in 2010-2018.
\end{abstract}

Keywords: Inequality of Income Distribution; Economic Growth, HDI; Distric/City Minimum Wage; Unemployment.

\begin{abstract}
Abstrak
Tingginya ketimpangan distribusi pendapatan yang terjadi di Provinsi D.I Yogyakarta menunjukkan pembangunan ekonomi belum berhasil membawa pemerataan bagi masyarakat. Untuk itu, diperlukan suatu analisis untuk mengetahui faktor yang mempengaruhi ketimpangan distribusi pendapatan dalam rangka menurunkan ketimpangan distribusi pendapatan yang terjadi di Provinsi D.I Yogyakarta. Tujuan dari penelitian adalah untuk mengetahui pengaruh pertumbuhan ekonomi, IPM, Upah Minimum Kabupaten/Kota dan Pengangguran terhadap ketimpangan distribusi pendapatan di kabupaten/kota Provinsi D.I Yogyakarta tahun 2010-2018. Penelitian ini menggunakan data sekunder yang diperoleh dari Badan Pusat Statistik (BPS) Provinsi D.I Yogyakarta. Data dalam penelitian berupa data panel yang terdiri dari data cross section 5 kabupaten/kota dan data time series tahun 20102018. Analisis data yang digunakan adalah analisis regresi data panel dengan model regesi Fixed Effect. Hasil analisis regresi menunjukkan bahwa pertumbuhan ekonomi tidak berpengaruh signifikan terhadap ketimpangan distribusi pendapatan. Sedangkan IPM, Upah Minimum Kabupaten/Kota dan Pengangguran berpengaruh signifikan terhadap ketimpangan
\end{abstract}


distribusi pendapatan. IPM berpengaruh negatif sedangkan Upah Minimum Kabupaten/Kota dan Pengangguran berpengaruh positif terhadap ketimpangan distribusi pendapatan di Provinsi D.I Yogyakarta tahun 2010-2018.

Kata kunci: Ketimpangan Distribusi Pendapatan, Pertumbuhan Ekonomi, IPM, Upah Minimum Kabupaten/Kota, Pengangguran.

How to Cite: How to Cite: Suryani, K. G., \& Woyanti, N. (2021). The Effect of Economic Growth, HDI, District/City Minimum Wage and Unemployment on Inequity of Income Distribution in Province of D.I Yogyakarta (2010-2018). Media Ekonomi dan Manajemen, 36(2), 170-180. doi: http://dx.doi.org/ 10.24856/mem.v36i2.1990.

\section{INTRODUCTION}

Economic development is basically aimed at improving people's welfare. The problem of inequality in income distribution will hinder development because it has a negative impact on the economic stability and political stability of a country. The increasing inequality of income distribution will widen the gap between the rich and the poor, thus becoming a challenge for economic development in Indonesia.

Inequality of income distribution in Indonesia as measured by the Gini Ratio shows a decline during the 2010-2018 period. However, inequality of income distribution in DI Yogyakarta Province has actually increased and has become the province with the highest inequality of income distribution in Indonesia (BPS, 2019). Inequality in income distribution is an important issue that must be addressed in order to improve people's welfare.

One of the factors thought to influence the inequality of income distribution is economic growth. The study conducted by Deyshappriya (2017) shows results consistent with Kuznets' theory, where the initial increase in economic growth will be followed by high inequality in income distribution in Asian countries. However, in the long run the increase in economic growth allows a fair redistribution of economic activity across the country and, as a result, income inequality may decrease.

Likewise, research conducted by Davtyan (2014) shows that economic growth has a negative relationship with inequality in income distribution in the US and Canada. So that economic growth is expected to be able to increase people's income and overcome the problem of inequality in income distribution.

Apart from economic growth, another factor that is thought to have an effect on inequality in income distribution is the achievement of the Human Development Index (HDI). HDI reflects the quality of human resources. Lee \& Lee (2018) in their research show that an increase in human capital as measured by educational attainment plays an important role in overcoming inequality in income distribution. Increasing education as part of human capital can increase income in the future. Meanwhile, Hariani (2019) in her research found that the unequal HDI between regions causes the inequality of income distribution to widen. Areas with high HDI have good human qualities, while areas with low HDI have relatively low human qualities.

Inequality of income distribution is related to the income received by the community. The income received is usually in the form of wages. The minimum wage is a policy that is useful for ensuring workers get a fair wage that includes meeting the standard of living needs of workers. A study conducted by Litwin (2015) shows that an increase in the real value of the minimum wage has an effect on reducing inequality of income distribution by redistributing wealth. The existence of a minimum wage causes the distribution of wealth from consumers and entrepreneurs to the workforce. Lin \& 
Yun's (2016) research also shows that the increase in minimum wages substantially contributes to reducing the inequality of income distribution in China.

On the other hand, research by Sungkar et al. (2015) shows that an increase in the minimum wage will increase the inequality of income distribution that occurs. This is in accordance with the neoclassical theory which argues that the provision of a minimum wage causes labor prices to increase which in turn leads to a reduction in demand for labor. The reduced demand for labor causes some people to lose their earned income so that the inequality of income distribution is widening.

Another factor that is thought to affect the inequality of income distribution is unemployment. If the number of people who do not work increases, the population who do not receive income or wages will also increase, so that the inequality of income distribution between the rich and the poor will worsen (Hariani, 2019). The results of Sheng's research (2011) also show that the unemployment rate and the inequality of income distribution have a positive correlation. The increase in the unemployment rate, which is indicated by the reduction in income earned, causes the inequality of income distribution to be higher.

This study aims to determine the effect of economic growth, HDI, District/City Minimum Wage and Unemployment on the inequality of income distribution in the districts/cities of DI Yogyakarta Province in 2010-2018. By knowing what factors are influencing, it is hoped that it can reduce the problem of unequal income distribution that occurs.

\section{LITERATURE REVIEW}

\section{Inequality of Income Distribution}

Inequality of income distribution is an unequal distribution of total national income among various households in a country (Todaro \& Smith, 2011). In other words, inequality of income distribution is the difference in the amount of income received by the community, resulting in greater income differences between groups in the community.

Inequality of income distribution can be measured by the Gini coefficient or the Gini ratio. The Gini coefficient is a measure of aggregate inequality that ranges from zero to one. If the Gini coefficient is zero it means perfect evenness, while if the gini coefficient is one it means perfect inequality. The calculation of the gini coefficient is based on the Lorenz Curve, namely by calculating the ratio of the plane that lies between the diagonal line and the Lorenz Curve divided by the area of half of the plane where the curve is located.

\section{Economic Growth}

Kuznets defined economic growth as an increase in the capacity in the long run to provide various economic goods to its population (Todaro \& Smith, 2011). The theory of economic growth according to Harrod-Domar stated that the rate of economic growth is determined jointly by the national saving ratio and the national capital-output ratio. Increased investment is required to increase aggregate expenditure.

The correlation between economic growth and income inequality can be illustrated by the inverted U-shaped Kuznets Curve. In the early stages of economic growth, it will increase inequality of income distribution due to the uneven distribution of income, but in the long run, even distribution will be more achieved until the level of inequality has decreased. The Kuznets curve can be generated by a continuous growth process stemming from the expansion of the modern sector, as a country progresses from a traditional economy to a modern economy (Todaro \& Smith, 2011). So that in the long run, when employment 
opportunities increase and traditional sectors also develop, the distribution of income will be stable or even.

\section{Human Development Index (HDI)}

The Human Development Index (HDI) is a composite index that can describe the development of human development in a measurable and representative manner. HDI is an important indicator to measure success in efforts to build the quality of human life and is useful for determining the level of development of a region / country. HDI is formed by three basic dimensions, namely long and healthy life, knowledge, and a decent standard of living.

According to Becker (in Lee \& Lee, 2018) human capital as indicated by the level of education has an effect on inequality of income distribution. Education plays an important role in determining a person's income level. In Human Capital theory it is also explained that every additional one year of school can increase a person's work productivity and income level (Anshari, et al, 2018). So that the higher of HDI, the higher the level of population productivity which will then lead to a higher level of income and will reduce the inequality of income distribution that occurs.

\section{District/City Minimum Wage}

The government sets a minimum wage based on the needs of a decent life and by taking into account productivity and economic growth. The wage system according to Mill (in Jhingan, 2012) stems from the very high elasticity of the labor supply in response to rising wages. Wages can be increased by increasing the aggregate capital fund used for recruiting labor or by reducing the number of workers. If wages rise, the labor supply will be high. Competition among workers will not only lower wages but also cause some workers to quit their jobs.

The relationship between minimum wages and inequality of income distribution can be explained in neoclassical economic theory which argued that minimum wages will increase inequality of income distribution (Sungkar, et al. 2015). The existence of a minimum wage provision causes the price of labor to increase which in turn causes a reduction in demand for labor. The reduced demand for labor causes some people to lose their earned income so that the inequality of income distribution is widening.

\section{Unemployment}

Unemployment according to Sukirno (2013) is a situation without work faced by workers, who have tried to find work but did not get it. Someone who faces this problem is called unemployed. Unemployment can occur due to a lack of aggregate spending. The greater the unemployment, the more groups of workers do not have income. Unemployment that is too large can reduce wages for low-income groups so that the inequality of income distribution is getting higher.

The relationship between the level of unemployment and inequality of income distribution can be explained in the findings of Sheng (2011) which shows that the unemployment rate and inequality of income distribution have a positive correlation. The increase in the unemployment rate which is indicated by the reduced income earned causes the inequality of income distribution to be higher.

Based on literature review, the conceptual framework of this study can be described in Figure 1. 


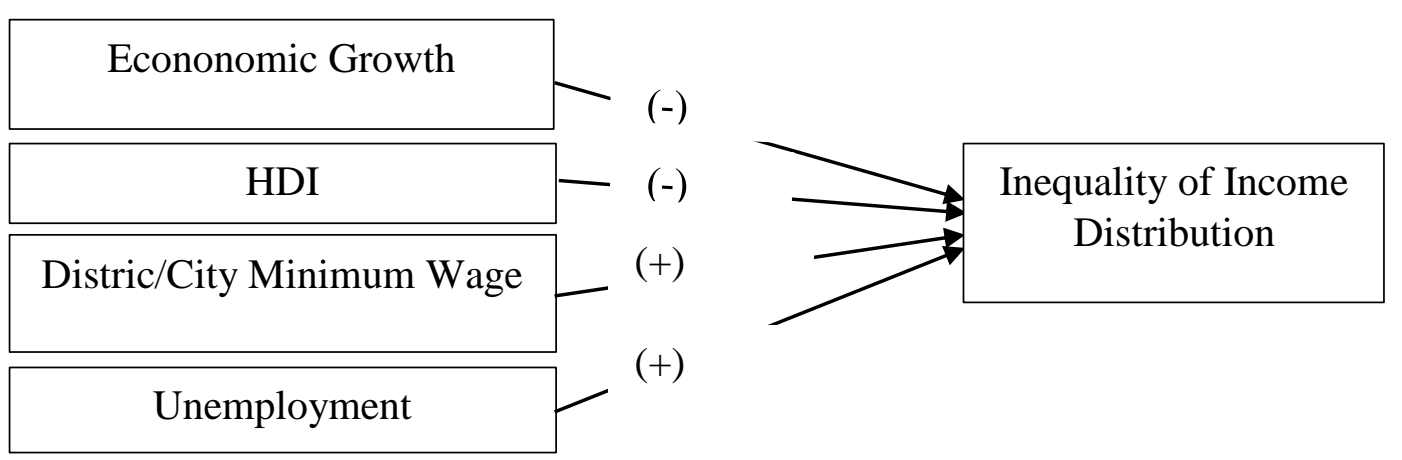

Figure 1. Conceptual Framework

Source : Davtyan (2014); Hariani (2018), modified.

\section{Operational Definition of Variables}

This study used one dependent variable and four independent variables. The dependent variable in this study is the inequality of income distribution. While the independent variables include Economic Growth, HDI, District/City Minimum Wage and Unemployment.

\section{Dependent Variable}

Inequality of income distribution is the unequal distribution of income received by the community. Inequality of income distribution is measured using the Gini coefficient or the Gini ratio. This study used the Gini Ratio data according to districts/cities in the province of D.I Yogyakarta in percentage units.

\section{Independent Variable Economic Growth}

Economic growth is the development of the production of goods and services in an economic area in a certain year against the value of the previous year which is calculated based on GDP / GRDP at constant prices (BPS, 2019). In this study, economic growth is measured using data on the GRDP growth rate at constant prices according to districts/cities in the Special Region of Yogyakarta Province and expressed in percentage units.

\section{Human Development Index}

HDI is a composite index used to measure the achievement of human development based on the basic components of the quality of human life. HDI is calculated as the geometric mean of the health index, education index and expenditure index in percent units. This study used HDI data according to districts/cities in the province of D.I Yogyakarta in 2010-2018.

\section{District/City Minimum Wage}

The District/City Minimum Wage is a minimum standard used by entrepreneurs to pay wages to employees in their work environment which applies in the District/City area. This study uses data from the District/City Minimum Wage in the D.I Yogyakarta Province in 2010-2018 in units of rupiah per month.

\section{Unemployment}

The Open Unemployment Rate is the percentage of the total unemployed against the total labor force. The Open Unemployment Rate indicates the large percentage of the workforce that is included in unemployment. The study used data on the Open Unemployment Rate by District/City in Yogyakarta Province in 2010-2018. 


\section{RESEARCH METHODS}

\section{Types and Sources of Data}

The type of data used in this research is quantitative data or data in the form of numbers. The data source used is secondary data obtained from BPS DI Yogyakarta Province. The type of data used is panel data from the cross section of 5 districts/cities in the DI Yogyakarta Province and time series from 2010 to 2018 (9 years) so that the number of observations is 45 observations.

\section{Method of collecting data}

The data collection method used in this research is the documentation method. The documentation method is to find and collect data about things or variables used from notes, books, transcripts, newspapers, magazines, and so on (Siyoto \& Sodik, 2015). The data in this study were obtained from the Yogyakarta Province Central Statistics Agency.

\section{Method of Analysis}

The analysis method used in this research is panel data regression analysis. Panel data regression analysis aims to determine the effect of the variable economic growth, HDI, District/City Minimum Wage and Unemployment on the inequality of income distribution in districts/cities in the DI Yogyakarta Province from 2010 to 2018. Panel data regression is a combination of cross section data with time series data, in which the same cross section units are measured at different times. To estimate the regression model using panel data, there are three approaches that can be used, namely: Common Effect Model / Pooled Least Square (PLS), Fixed Effect Model (FEM) and Random Effect Model (REM) (Gujarati \& Porter, 2013).

The model in this study is based on the model used by Nangarumba (2015), namely by transforming the panel regression equation into a logarithmic functional form. The use of this functional form aims to reduce the resulting coefficient value due to differences in the unit value between variables. In this study, the District/City Minimum Wage variable uses the rupiah currency unit so it needs to be transformed so that the resulting coefficient value is not too large, while other variables use percentage units (decimal) so that it does not need to be transformed. The equation model after being transformed into logarithmic form is as follows.

INEQUALITY $_{\text {it }}=\beta 0-\beta 1 \mathrm{EG}_{\mathrm{it}}-\beta 2 \mathrm{HDI}_{\mathrm{it}}+$
$\beta 3 \log _{-} \mathrm{MW}_{\mathrm{it}}+\beta 4 \mathrm{OUR}_{\mathrm{it}}+\varepsilon_{\mathrm{it}} \ldots \ldots$. (1)

Information :

INEQUALITY= Income inequality

$\mathrm{EG}=$ Economic Growth

HDI = Human Development Index

MW $=$ District/City Minimum Wage

OUR $=$ Open Unemployment Rate

$i \quad=$ cross section

$t \quad=$ time series

$\beta 0=$ constant

$\beta 1, \beta 2, \beta 3, \beta 4=$ regression coefficient

$\varepsilon_{i t} \quad=$ erorr term

\section{RESULTS AND DISCUSSION}

\section{Best Model Selection}

To find out which model is most appropriate for panel data processing, it is necessary to carry out several tests, namely the Chow test and the Hausman test. The Chow test is used to determine between the two models to be selected for data estimation, namely the Pooled Least Square Model (PLS) or the Fixed Effect Model (FEM). Meanwhile, the Hausman Test is used to determine which Fixed Effect (FEM) Model or Random Effect (REM) Model to choose. From the Chow test and Hausman test that have been carried out in Table 1, it is found that the best model used in this study is the Fixed Effect Model. 
Table 1. Chow Test and Hausman Test

\begin{tabular}{|c|c|c|c|}
\hline $\begin{array}{l}\text { Chow Test (Pooled vs } \\
\text { Fixed Effect) }\end{array}$ & $\begin{array}{l}\text { Prob. } \\
0.0001\end{array}$ & $\begin{array}{c}\text { Test Indicator } \\
\text { Prob. F }<\text { Sig } \\
(0.0001<0.05) \\
\end{array}$ & $\begin{array}{c}\text { Information } \\
\text { Fixed Effect selected } \\
\text { model } \\
\end{array}$ \\
\hline $\begin{array}{l}\text { Hausman Test (Fixed } \\
\text { Effect vs Radom Effect) }\end{array}$ & $\begin{array}{l}\text { Prob. } \\
0.0000\end{array}$ & $\begin{array}{c}\text { Test Indicator } \\
\text { Prob. F }<\text { Sig } \\
(0.0000<0.05)\end{array}$ & $\begin{array}{c}\text { Information } \\
\text { Fixed Effect selected } \\
\text { model }\end{array}$ \\
\hline
\end{tabular}

Source: Eviews 10

\section{Classic Assumption Detection}

\section{Normality Detection}

Based on the results of panel data regression, the Jarque-Bera probability value is 0.382746 or greater than 0.05 , meaning that the data is normally distributed. These results conclude that the assumptions normally distributed in the model are fulfilled.

\section{Multicollinearity Detection}

Multicollinearity detection shows that the correlation value between independent variables is smaller than $0.8(\mathrm{r}$ $<0.8$ ), which means that the model is free from multicollinearity problems, so that the assumption of multicollinearity does not occur in the model.

\section{Heteroscedasticity Detection}

The results of heteroscedasticity detection using the Glejser test showed that all independent variables had a probability of more than 0.05 ( $p$-value> 0.05). This shows that the model is homoscedastic or the assumption does not contain fulfilled heteroscedasticity.

\section{Autocorrelation Detection}

The results of autocorrelation detection using the Durbin-Watson (DW) test show that the model is affected by autocorrelation problems. According to Gujarati \& Porter (2013), the Generalized Least Square (GLS) method is a method to fix autocorrelation problems. After the equation is estimated using the GLS method (SUR cross-section), the dw value is 2.032967. The dw value is greater than $\mathrm{dU}$ and less than 4-dU $(1.7200<2.032967$ $<2.2800$ ) so it can be concluded that there is no autocorrelation problem in the model.

\section{Regression Analysis Results}

From the results of the model selection that has been done, it is known that the fixed effect is the best model to use. As for the tests that have been done before, the model has passed the detection of classical assumptions after being repaired by the Generalized Least Square / GLS method (SUR cross-section). So that the panel data regression model with fixed effects is also estimated using the Generalized Least Square / GLS (SUR cross-section) method. The estimation results can be seen in Table 2 . The equation model result as follows.

$$
\begin{aligned}
& \text { INEQUALITY }=-2.961704-0.001351 E G \\
& -0.022650 H D I+0.360076 L O G \_M W \\
& +0.0084940 U R+e
\end{aligned}
$$


Table 2. Fixed Effect Panel Regression

\begin{tabular}{lcccc}
\hline \multicolumn{1}{c}{ Variable } & Coefficient & t-Statistics & Glejser Test (Prob) & Probability \\
\hline EG & -0.001351 & -0.442534 & 0.7425 & 0.6608 \\
HDI & -0.022650 & -3.925111 & 0.9551 & 0.0004 \\
LOG_MW & 0.360076 & 9.038313 & 0.5997 & 0.0000 \\
OUR & 0.008494 & 2,522909 & 0.1612 & 0.0162 \\
C & -2.961704 & -15.29404 & 0.0590 & 0.0000 \\
\hline R-Squared & 0.961704 & & & \\
Adjusted R-Squared & 0.947816 & & & \\
F-statistic & 81,73325 & & & \\
Prob. (F-statistic) & 0.000000 & & & \\
DW stat & 2.032967 & & & \\
Prob (Jarque-Bera) & 0.382746 & & & \\
Obs. & 45 & & & \\
\hline
\end{tabular}

Source: Output Eviews 10

\section{Significance Test}

\section{Coefficient of Determination $\left(\mathbf{R}^{\mathbf{2}}\right)$}

From Table 2 it is known that the coefficient of determination $\left(\mathrm{R}^{2}\right)$ is 0.947816 . This value shows that the ability of the variable economic growth, HDI, District/City Minimum Wage and Unemployment is able to explain the variable inequality of income distribution by $94.78 \%$, while the remaining $5.22 \%$ is explained by other variables outside the research model.

\section{Simultaneous Test (F test)}

Based on panel data regression, it was obtained that the F-count value was 81.73325 with a probability $\mathrm{F}$ of 0.000000 (prob. $\mathrm{F}<0.05$ ). This shows that all independent variables, namely economic growth, HDI, District/City Minimum Wage and Unemployment, have a significant effect simultaneously on inequality of income distribution.

\section{Partial Test (t test)}

The $t$ test analysis is seen from the probability value of the independent variable, which if the probability is smaller than the 5\% significance level, the variable is significant in influencing the dependent variable. The regression results show that the variables that have a significant effect on inequality of income distribution are HDI, District/City Minimum Wage and
Unemployment. Meanwhile, economic growth does not have a significant effect on inequality of income distribution.

\section{Discussion}

\section{The Effect of Economic Growth on Inequality of Income Distribution}

The regression results show that partially economic growth does not have a significant effect on inequality of income distribution. The coefficient of the economic growth variable is -0.001351 with a probability of 0.6608 , which means that if economic growth increases by $1 \%$ it will not affect or will not be followed by a decrease in inequality of income distribution by 0.001351 percent. This result is not in accordance with the results of Davtyan's (2014) research which shows that economic growth has a negative effect on inequality in income distribution. The results of this study are also different from Deyshappriya's (2017) research which shows consistency with Kuznets theory, where the initial increase in economic growth will be followed by a high inequality of income distribution.

However, the results of the study are in accordance with Pangkiro's (2016) research where economic growth has no effect on inequality in income distribution. According to Pangkiro (2016) in his research, he stated that high economic 
growth has not been the answer to the decline in inequality of income distribution. This is because the economic growth that occurs is the result of contributions to sectors that absorb few workers. Meanwhile, sectors with a large number of workers have not yet contributed to economic growth. This then causes economic growth to have no effect in reducing inequality of income distribution, as happened in Yogyakarta Province.

\section{The Effect of HDI on Inequality of Income Distribution}

The regression results show that partially the HDI variable has an effect on the inequality of income distribution in the districts/cities of Yogyakarta Province. The HDI variable coefficient is -0.022650 with a probability of 0.0004 , which means that if the HDI increases by $1 \%$ it will have an effect or will be followed by a decrease in inequality of income distribution by 0.022650 percent. The results of the study contradict Hariani's (2019) research which shows that HDI has a positive and significant effect on inequality in income distribution. The inequality of HDI between regions encourages the imbalance of development that occurs so that income inequality between regions is widening.

However, these results are consistent with Lee \& Lee's (2018) research which shows that HDI has a negative effect on inequality of income distribution. In his research, it was explained that education as an HDI indicator plays an important role in reducing inequality of income distribution. This is also in accordance with the Human Capital theory which stated that education is able to increase one's productivity so that it is useful for increasing the income earned. The higher the level of education, the higher the income.

\section{The Effect of District/City Minimum Wage on Inequality of Income Distribution}

The regression results show that the District/City Minimum Wage variable partially affects the inequality of income distribution in the districts/cities of Yogyakarta Province. The District/City Minimum Wage variable coefficient is 0.360076 and the probability is 0.0000 , it means that if the District/City Minimum Wage increases by $1 \%$, it affects or will be followed by an increase in income inequality by 0.360076 percent. The results of this study are in accordance with the results of research by Sungkar et al. (2015) where the minimum wage has a positive and significant effect on income inequality in Indonesia. The results also agree with the Neoclassical economic theory which argued that an increase in the minimum wage will increase income inequality rather than reduce it. The existence of a minimum wage provision causes the price of labor to increase which in turn causes a reduction in demand for labor. The reduced demand for labor causes some people to lose their earned income so that income inequality is widening.

However, Litwin's research (2015) shows different results, namely the minimum wage has a negative effect on inequality in income distribution. An increase in the real value of the minimum wage will reduce inequality in income distribution due to the redistribution of wealth from consumers and entrepreneurs to low-paid workers. Research by Lin \& Yun (2016) also shows that increases in minimum wages substantially contribute to reducing inequality in income distribution.

\section{The Effect of Unemployment on Inequality of Income Distribution}

The regression results show that the unemployment variable partially affects the inequality of income distribution in the districts/cities of Yogyakarta Province. The regression coefficient of the 
unemployment variable is 0.008494 with a probability of 0.0162 , which means that if the Unemploymeny increases by $1 \%$, it will affect or will be followed by an increase in inequality of income distribution by 0.008494 percent. This result is consistent with the research of Sheng (2011) which shows that the unemployment rate and inequality of income distribution have a positive correlation. The increase in the unemployment rate results in a decrease in the income earned, which causes the inequality of income distribution to increase. These results also support the statement of Sukirno (2013) which explains that the greater the unemployment, the more groups of workers who do not have income. Unemployment that is too large can reduce wages for low-income groups so that the inequality of income distribution is getting higher.

\section{CONCLUSIONS AND RECOMMEN- DATIONS}

From the analysis, it is concluded that the HDI, District/City Minimum Wage and Unemployment have an effect on the inequality of income distribution. Meanwhile, economic growth does not have a significant effect on inequality of income distribution. Economic growth, which reflects the level of population welfare, has no effect because the economic growth that occurs comes from the contribution of sectors that absorb a few workers, while the sectors with the most labor absorption have a small contribution to economic growth. HDI, which reflects the quality of human resources, has a negative effect on inequality in income distribution. This is because a high HDI will increase one's productivity so that the income earned will increase and encourage a decrease in inequality of income distribution. The District/City Minimum Wage has a positive effect on inequality of income distribution because an increase in the minimum wage will cause a reduction in demand for labor so that some workers will lose their earned income. Unemployment which is indicated by the open unemployment rate has a positive effect on inequality of income distribution because the more unemployed, the more groups of the population do not have income which can then increase the inequality of income distribution.

The recommendation from the results of this study is that the government is expected to increase HDI, especially in underdeveloped areas by building infrastructure that supports the increase in HDI, such as building schools, health facilities and business units. This is because HDI has an effect in reducing inequality of income distribution, so that the distribution of HDI in each region needs to be done. Furthermore, because the District/City Minimum Wage has the effect of increasing inequality of income distribution, the government needs to set new wage standards that are as close as possible to basic human needs by taking into account every sector of the necessities of life. And lastly, the government needs to open up more job opportunities so that unemployment in the districts / city of Yogyakarta Province will decrease.

\section{REFERENCES}

Anshari, M., Ashar, Z., \& Ariusni. (2018). Analisis Pengaruh Pendidikan, Upah Minimum Provinsi dan Belanja Modal Terhadap Ketimpangan Pendapatan di Seluruh Provinsi di Indonesia. EcoGen, 1(3), 494-502.

Davtyan, K. (2014). Interrelation among Economic Growth, Income Inequality, and Fiscal Performance: Evidence from Anglo-Saxon Countries. Universitat de Barcelona, 1-45. 
Deyshappriya, N. P. (2017). Impact of Macroeconomic Factors on Income Inequality and Income Distribution in Asian Countries. Asian Development Bank Institute (ADBI) 696. http://hdl.handle.net/10419/163195

Gujarati, D. N., \& Porter, C. D. (2013). Dasar-Dasar Ekonometrika. Jakarta: Salemba Empat.

Hariani, E. (2019). Analisis Faktor-Faktor yang Mempengaruhi Ketimpangan Pendapatan di 38 Kabupaten/Kota Jawa Timur Tahun 2012-2015. The International Journal of Applied Business, 3(1), 13-23.

Jhingan, M., L. (2012). Ekonomi Pembangunan dan Perencanaan. Jakarta: Rajawali Press.

Lee, J. W., \& Lee, H. (2018). Human Capital and Income Inequality. Journal of the Asia Pacific Economy, 1-29. https://doi.org/10.1080/13547860.2 018.1515002

Lin, C., \& Yun, M. S. (2016). The Effects of the Minimum Wage on Earnings Inequality: Evidence from China. IZA Discussion Paper No. 9715.

Litwin, B. S. (2015). Determining the Effect of the Minimum Wage on Income Inequality. Student Publication Gettysburg College, 119.

https://cupola.gettysburg.edu/stude nt_scholarship/300

Nangarumba, M. (2015). Analisis Pengaruh Struktur Ekonomi, Upah Minimum Provinsi, Belanja Modal, dan Investasi Terhadap Ketimpangan Pendapatan di Seluruh Provinsi di Indonesia Tahun 2005-2014. JESP, 7(2), 926.
Pangkiro, H. A. K. (2016). Analisis Pertumbuhan Ekonomi dan Kemiskinan Terhadap Tingkat Ketimpangan di Provinsi Sulawesi Utara. Jurnal Berkala Ilmiah Efisiensi, 16(1), 339-351.

Sheng, Y. (2011). Unemployment and Income Inequality: A Puzzling Finding from the US 1941-2010. Nanjing Normal University. http://ssrn.com/abstract=2020744

Siyoto, S., \& Sodik, M. A. (2015). Dasar Metodologi Penelitian. Yogyakarta: Literasi Media Publishing.

Sukirno, S. (2013). Makroekonomi Teori Pengantar. Jakarta: RajaGrafindo Persada.

Sungkar, S. N., Nazamuddin, \& Nasir, M. (2015). Pengaruh Upah Minimum Terhadap Ketimpangan Pendapatan di Indonesia. Jurnal Ilmu Ekonomi, 40-53.

Todaro, M. P., \& Smith, S. C. (2011). Pembangunan Ekonomi edisi ke sembilan. Jakarta: Erlangga. 